SPONTANEOUS CHROMOSOME ALTERATIONS IN CREPIS TECTORUM L.

BY

M. NAVASHIN 
Tniverste of Chliforna Publications in Agriculteral helexces Folume 6, No. 7. pp. 201-206, 1 figure in text Issued April 1 1, 1931

University of Californil Press BERKELEY, CALIFORNIA

Cambripge T'anersity Press LONDON, ENGLAND 


\title{
SPONTANEOUS CHROMOSOME ALTERATIONS IN CREPIS TECTORUM L.
}

BY

\author{
M. NAVASHIN*
}

During the summer of 1930 many progenies derived from Crepis tectorum plants possessing aberrant chromosome sets were grown for the purpose of studying the transmission of chromosonal abnormatities. It was found in the great majority of eases, in full aceord with expectation, that chromosomal abnormalities were transmitted as such to a certain part of the offispring. Thus, for instance, simple trisomics threw identical trisomies in proportions which varied according to the kind of the extra chromosome and according to the individual. Individuals possessing a typical chromosome structure (for instance, translocated chromosomes) transmitted their abnormal chromosomes to a certain percentage of their offspring. In three cases, however, the behavior of the tested individuals was entirely different. They produced, indeed, among their progeny not only the expected chromosomal abnormalities, i.e., aberrations identical with those which were characteristic of them, but there appeared also in the immediate offspring some entirely new chromosomal alterations, and, furthermore, these oceurred in unusually high numbers. In the following pages will be given a short diseussion of these peculiar cases observed among progenies $30.503,30.511$, and 30.515 .

Progeny 30.503 was grown from open pollinated seed collected from a simple trisomic. It consisted of seven plants from which two were selected for cytological investigation because of their somewhat abnormal appearance. One of the two plants died early in development; the other was subjected to eytological investigation.

From the seventeen root-tips investigated thirteen proved to be entirely normal. Four of them uniformly contained an abnomal chromosome complement shown in figure 1, $d$. From an inspection of this figure one can see that the alteration involves two chromosomes, mamely, the two A-chromosomes (see, for a normal complement of

* Now of the Division of Experimental Evolution, Timiriazev Biological Institute, Moseow, U.S.S.R. 
Crepis tectorum, fig, $1, h$ ) which at first sight seem to be entirely lacking. Closer examination and comparison with the normal complement make it possible to give to this phenomenon an adequate interpretation. It is easy to see that two conspicuous structures have replaced the two $\mathrm{A}$-chromosomes in this figure and that the large $\checkmark$-shaped chromosome and the other very short one are simply products of rearrangement of the material which normally composes the two A-chromosomes. Obviously, the proximal fragment of one of the A-chromosomes became detached as a diminished autonomous chromosome; the rest of the same $\Lambda$-chromosome (its distal fragment) has fused with the proximal end of the other, otherwise unaltered A-chromosome, making its smaller arm correspondingly longer and thus producing a large $V$-shaped structure.

The npper parts of the plant in question not having been investigated, nothing can be said abont their chromosomal constitution. It appears probable, however, that certain shoots possessed some ehromosomal abnomalities since they displayed a very low fertility. The latter ciremmstance would be expected in ease the above deseribed ehromosomal alteration was present also in spore mother cells.

Progeny 30.511 was derived from open pollinated seed prodneed by a simple trisomic. From the total of forty plants, five appeared to be more or less abnormal and the remaining thirty-five were disearded. Cytological investigation of the root-tips of these morphologically aberrant individuals showed that two of them were simple trisomics of the triple-b type (like the parental plant), wo were apparently normal, and one was a chromosomal chimera. Among many root-tips there was only one eytologically abnommal it was mniformly altered in all its cells in a most conspicuons way. The alteration in this ease involved the two D-chromosomes (fig, 1, $a, b$, and c). As may be easily deduced, the proximal fragment of one of the D-chromosomes became an antonomous small satellited chromosome, the distal portion of the same chromosome being permanently a.t ached to the satellite of the second (otherwise unaltered) D-chromosome. The resulting alteration of the chromosome complement was thus expressed by the presence of one minute satellited chromosome and another very large one distinguished by its musually larege rylindrical satellite.

This particular plant did not show any abnormalities as to its fortility, ete., so that it seemed rather probable that this alteration was localized in a small part of the root system. 
Progeny 30.515 eame from open pollinated seed yielded by a chromosomally aberrant plant which possessed a very small spherical fragment in addition to its otherwise apparently normal chromosome complement. Among the total of twenty-four plants, five were selected for cytological investigation since they were distinguished by various morphological peculiarities. Only one of them (plant 3) was probably normal in its chromosome complement, but owing to the lack of good roots, this could not be established with full certainty. The remaining four plants were all chromosomally abnormal, and moreover, each of them in a different way.
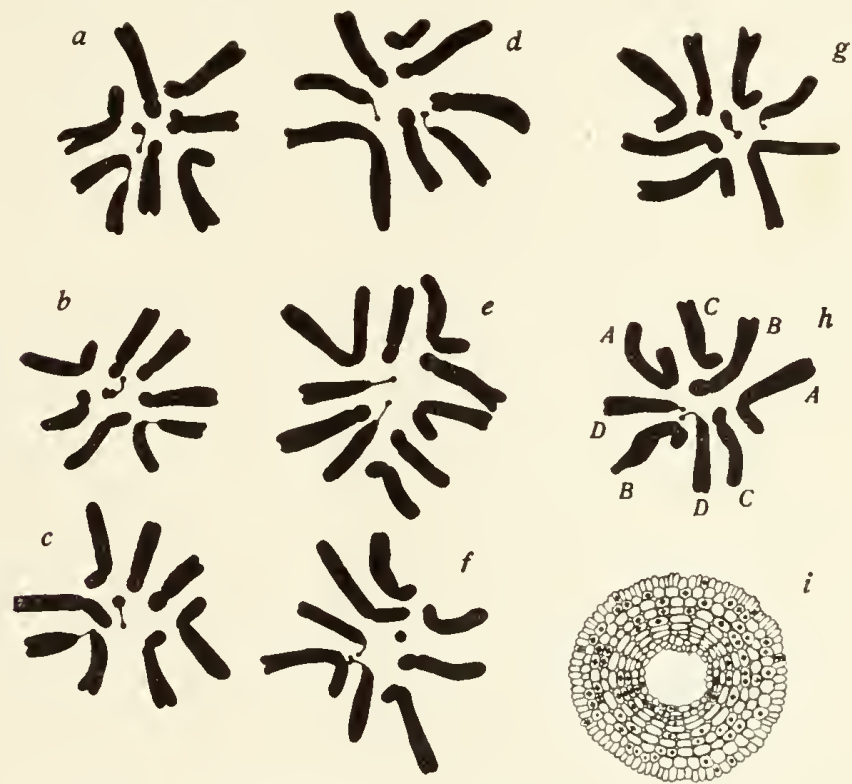

Fig. 1. Somatic ehromosomes from the root-tips of altered indiriduals of Crepis tectorum.

$a, b, c$, three netaphases from the single altered root of the plant $30.511-\underline{2}$. One of the two D-chromosomes was fragmented; its proximal fragment constitutes a small satellited chromosome, the distal portion being permanently fused with the satellite of the other, otherwise unaltered D-chromosome.

d, plant 30.503-2. One of the two A-chromosomes fragmented; its proximal fragment functions as a small autonomous eliromosome; the distal portion is attached to the proximal end of the other A-chromosome thus forming a large V-shaped structure.

$e, f, g$, different plants from progeny 30.515 slowing various chromosoma? alterations.

h, a normal chromosomal complement from the chimeral root belonging to plant $30.515-2$ (ef. fig. $1, g$ ).

$i$, diagram showing the distribution of altered and normal mitoses in the root of plant 30.515-2 (cf. fig. 1, g). Crosses indicate alteled cells, disclets, norma! (cells.

See also the text. Magnification 1700 diameters, except diagram $i$ which is drawn to a much smaller scale. 
Plant 1 was a simple triplo-A trisomic, all its roots uniformly possessing an extra A-chromosome.

In plant 2 one root out of fourteen was partly altered in its chromosomes. There appeared a sector forming about 75 per cent of the whole root in which the proximal fragment of one of the two D-chromosomes became autonomous (as in the case of progeny 30.503), the distal portion of the same chromosome being fused with the proximal end of one of the B-chromosomes, thus forming again a large $V$-shaped structure (fig. $1, g$ and $i$ ).

Plant 4 (fig. 1, e) was uniformly altered in all its roots. In this case there was prescnt one C-chromosome extra, and, in addition, a large $V$-shaped structure apparently derived from fusion, as in the instances described above.

Finally, plant 5 displayed the same peculiarity as the parental individual, namely, one of its roots contained in all its cells a very small spherical fragment (fig. $1, f$ ).

None of the above chromosomal abnormalities seemed to influence the mitotic process, nor did they seem to affect in the slightest degree the cell sizes or the vitality of the cells, etc. The latter was especially clear in the case of plant 30.515-2 where the sector of the root containing the altered chromosomes did not differ in regard to its cell divisions, cell size, shape, etc. from the chromosomally normal part of the root (cf. fig. 1, i). It shoukd be conchided, therefore, that even snch profound rearrangements of the chromosome material as those described above have no physiological effect whatever, at least so far as roots are concerned. One can hardy donbt, moreover, that they also produce no effect upon any other somatic tissue, at least in the earliex stages of its development.

The observations reported here not only add some new cases of chromosomal alterations to those previously known to ocenr in Crepis spontaneously (M. Navashin, 1926) or after the x-ray treatment (II. Navashin, 1931), but they also throw some light upon the conditions under which such chromosomal alterations are most likely to oceur. First, it may easily be seen that in the majority of cases they originate in somatic mitoses and sometimes very late in ontogeny because the majority of individnals developing them are chmeras. Secondly, it seems probable that there exists some peculiar condition in certain individuals, which makes their chromosome structure and the chromosomal distribution labile and subject to frecuent alterations in rarious ways. It may be suggested that just these three individuals which 
gave rise to the progenies reported above possessed some inherent and perhaps heritable imstability of chromosome behavior, which could account for the fact that, of their offspring, an mnusually high proportion of individuals was altered in several different ways. It is necessary to point out in this eomection that the frequency of spontaneous chromosomal alterations normally does not reach even 0.1 per cent, while in the above cases the corresponding frequency was almost one hundred times as high.

While chromosomal alterations representing only rearrangements of the chromosome material (dislocations) could hardly produce any immediate visible effect, some of them would inevitably lead to changes in chromosome affinity. Thus, for example, if plant 30.515-2 (fig. 1, g) could transmit its chromosomal peculiarity in homozygous form, individuals could arise which would possess an entirely new node of chromosome conjugation in meiosis. From what is known now of homozygous translocation in Drosophila melanogaster (Dobzhansky, 1930 ), such organisnis can really exist and, moreover, can be fertile. If, now, such an individual should be crossed with the original normal form, the hybrid would inevitably suffer from meiotic disturbances involving the translocated chromosomes, in the case referred to above, chromosomes B and D. For the normal B-chromosome will be attraeted by one part of the fusion chromosome, the D-chromosonre will tend to conjugate with the other part of the fusion chromosome, and the small free fragment of the D-chromosome will be attracted by the corresponding part of the D-chromosome. In such a hybrid normal reduction division would be impossible and the homozygous form possessing the dislocated chromosomes would become more or less genetically isolated from its progenitor. Thus it seems probable that certain chromosome alterations of the type deseribed above may play an important rôle in the initial steps of species formation.

It should be noted that alterations originating in undifferentiated sporophytic tissue would have a decided advantage over those arising during gametogenesis. For, in ease the altered sporophytic tissue should produce reproductive organs, altered functional gametes might arise at once in great numbers and thus the new chromosome organization would be transmitted to the offspring more certainly than in the case of oceasional formation of single aberrant germ cells during sporogenesis.

The above facts may be advantageonsly applied also to the explanation of some characteristic chromosome relations existing among 
species. Thus, for instance, the origin of the large V-shaped chromosomes typical of many species, especially of the pulchra-group in Crepis (Babeock and Navashin, 1930) may be attributed with a fair degree of probability to fusion of the sort deseribed above. The occurrence of very small satellited chromosomes (for instance. in Crepis parviflora, loc. cit.) may be explained as a result of fragmentation, since the D-chromosomes are especially apt to detach free proximal fragments. Finally, chromosomes with unusually large satellites. as in Crepis setosa with its unique satellited chromosone, could arise through translocation of a considerable chromatin portion to the satellite (ef. fig. 1, $a, b$, and $c$ ).

All these considerations are concerned with translocations or mere rearrangements, first designated dislocations (M. Navashin, 1926). If, in addition, some gain or loss of chromosome material takes place, one would deal with the change of genic balance, and, consequently, with more or less far-reaching changes in the organization of the individual bearing in its cells these new genetic conditions. It is obvious that any heterozygous dislocation would ultimately result in gain and loss of chromatin material in succeeding generations owing to segregation of chromosomes. And, if not incompatible with life, these may result in variations of evolutionary significance. For there can be hardly any doubt that the evolution of Crepis species was primarily based upon changes in the quantity of the material contained in the individual ehromosomes (cf. Babeock and MI. Navashin, 1930).

Further investigation is now in progress. Attention will be devoted chiefly to the study of the transmission of the presumed hereditary lability of ehromosome behavior and to the problem of obtaining homozygous translocations.

\section{LITERATURE CITED}

Babcock, E. B., and Navashin, MT

1930. The Genus Crepis. Bibliographia Genetiea, 6:1-90.

DoBzhansKY, T.

Transloeations involving the third and the fourth chromosomes of Drosophila melanogaster. Geneties, 15:347-399.

Navashin, M. (NaWaschin, M.)

1926. Variabilität des Zellkerus bei Crepis-Arten in Bezug auf die Artbildung. Zeitsehr. Zellforseh. mikr. Anat., 4(2):171-215.

1931. On ehromosome alterations induced by $x$-rays. Amer. Nat., 65: (in press). 